\title{
Bee Community in Open-Field Tomato Crop and Pollination Effect by Wild Bees on the Fruit Production
}

\author{
Fernando M. Barbosa ${ }^{1,2}$, José C. Zanuncio ${ }^{3}$ \& Lucio Antônio de O. Campos ${ }^{4}$ \\ ${ }^{1}$ Departamento de Entomologia, Universidade Federal de Viçosa, Viçosa, Brazil \\ ${ }^{2}$ Departamento de Produção, Instituto Federal de Educação, Ciência e Tecnologia do Norte de Minas Gerais, \\ Januária, Brazil \\ ${ }^{3}$ Departamento de Entomologia/BIOAGRO, Universidade Federal de Viçosa, Viçosa, Brazil \\ ${ }^{4}$ Departamento de Biologia Geral, Universidade Federal de Viçosa, Viçosa, Brazil \\ Correspondence: Fernando M. Barbosa, Departamento de Produção, Instituto Federal de Educação, Ciência e \\ Tecnologia do Norte de Minas Gerais, Fazenda São Geraldo, 39480-000, Januária, Minas Gerais State, Brazil. \\ Tel: 55-383-629-4600. E-mail: fernandosagarana@gmail.com
}

Received: February 16, 2019

Accepted: March 20, 2019

Online Published: May 15, 2019

doi:10.5539/jas.v11n6p86

URL: https://doi.org/10.5539/jas.v11n6p86

\begin{abstract}
Bees are important components of the pollinator community of most ecosystems, contributing to the production of crops. The knowledge on the bees'fauna associated with crops and the pollination effect performed by bees on the fruit production and quality is important to the design, planning, and execution of projects to conserve pollinator populations in agricultural systems. The objectives of this work were to identify bees visiting tomato flowers, verify the climate variable and the day period on bee forage activity, and to evaluate the fruit production with different pollination types. The study was conducted from July 2015 to September 2017 in the Norte de Minas and Zona da Mata region, Minas Gerais state, Brazil. Eleven tomato fields were sampled. Fruit set and fruit quality from different pollination methods was evaluated with the following treatments: single visit (SV), open pollination (OP), mechanical pollination (MP) and control (self-pollination) (C). A total of 1,998 individuals distributed in Andrenidae, Apidae, and Halictidae families were collected, with greater abundance and species richness for Apidae. The tomato fruit mass was higher in the OP than in the SV and MP, which differed from the C. The high abundance of Exomalopsis analis and its occurrence in all fields, allied to its sonication behavior, indicate that this species is an important pollinator of the tomato. The tomato does not depend exclusively on bee pollination, but this improves its yield and quality, especially when performed by individuals of different species.
\end{abstract}

Keywords: Apidae, crop, pollinators, tomato, yield

\section{Introduction}

Pollinators provide essential services for the reproduction of wild plants, and they increase yield of many crops (Gallai et al., 2009; Holzschuh et al., 2012). More than 75\% of leading global food crop depend on animal-mediated pollination to some degree (Klein et al., 2007), and insects are the main biotic pollinators (Gallai et al., 2009). Among insects, wild bees are efficient pollinators of cultivated plants (Garibaldi et al., 2013), increasing the yield and improving the quality, shelf-life, and commercial value of foods (Klatt et al., 2013; Brittain et al., 2014).

Despite the importance of bees for agricultural production, the decline of their populations in many regions of the world has raised concerns about food production (Potts et al., 2005; Burkle et al., 2013). Intensification and change in land use, pesticide spraying, climate change, pest and pathogen proliferation, and introduced exotic species are factors that, alone or combined, contribute to declining bee populations (Potts et al., 2005; Goulson et al., 2008; Eeraerts et al., 2017). Among these factors, the agricultural intensification is characterized by increased agrochemicals input, tillage, large crops and loss and fragmentation of natural or semi-natural habitats (Kennedy et al., 2013; Deguines et al., 2014; Cusser et al., 2016). These changes cause isolation of natural populations and reduce food sources and nesting sites (Ferreira et al., 2013), thus negatively influencing pollinator communities (Connelly et al., 2015; Mogren et al., 2016; Zou et al., 2017). 
Agricultural systems support a less diverse community of bees, and most ecosystem services tend to be provided by a few dominant species (Kleijn et al., 2015; Winfree et al., 2015; Zou et al., 2017). However, a more diverse pollinator community appeared to enhance pollination efficiency through spatial and temporal complementarity in its pollination behavior, suggesting that a single or a few efficient species may not provide the same benefits as a rich community of functionally distinct species (Rader et al., 2016; Eeraerts et al., 2017).

The tomato is one of the most consumed vegetables with a global production in 2016 of about 177 million tons (FAOSTAT, 2018). Tomato flowers are hermaphrodite, nectar-free, and have anthers with poricidal dehiscence that are fused (forming a cone around the stigma). Pollen release depends on vibration, which is known as buzz pollination (De Luca \& Vallejo-Marin, 2013). Despite being a self-compatible plant, pollination by bees has proven to increase tomato yield (Bartelli \& Nogueira-Ferreira, 2014; Deprá et al., 2014; Strange, 2015).

Knowing the bees' fauna associated with crops and how these insects impact yield is important to outline strategies that promote the increase and conservation of pollinators, considering the increase in the demand for food and the loss of diversity in agroecosystems. Thus, the objectives of this study were to identify bees visiting tomato flowers; verify the effect of the climate variables and day period on bees forage activity; and to evaluate the fruit quality resultant from different pollination types.

\section{Material and Methods}

\subsection{Study Site}

The study was conducted from July 2015 to September 2017 in the municipalities of Cajuri and Coimbra (Zona da Mata region) and Januária and Manga (Norte de Minas region), Minas Gerais state, Brazil. The Zona da Mata region is characterized by relatively heterogeneous landscapes with intensively managed coffee crop, annual crops, grasslands, forests and natural habitat (predominantly, Atlantic forest). The Norte de Minas landscape has small crops $(<1 \mathrm{ha})$ of fruit trees, vegetables, pastures and less than $10 \%$ of native vegetation, except for Manga which has a predominance of large cultivated areas (>30 ha) with annual crop, pasture, pumpkin, and tomato. Information on the sites sampled is available in Appendix A.

\subsection{Bee Survey}

Forty-six days were spent to sampling 11 fields. Bees visiting tomato flowers were collected from July to September 2015; March to May 2016; March and April 2017; and August and September 2017. In small fields (< $0.30 \mathrm{ha}$ ), we walked transects along all rows. In larger fields, we surveyed two areas ( $100 \mathrm{~m}$ long by $12 \mathrm{~m}$ wide), located on the edge of the crops. Each field was sampled between 8 a.m. and 2 p.m. during 20-30 min/h on dry and warm days $\left(>20^{\circ} \mathrm{C}\right)$ with low wind speeds. Temperature and humidity were recorded every hour with a thermohygrometer. All bee visitors contacting the tomato flowers were sampled with a sweep net, and subsequently killed with ethyl acetate in a killing jar. Bee samples per site and sampling period were pooled, sorted, pinned, labeled, and identified at species level. Voucher specimens were deposited at the Entomology Museum of the Universidade Federal de Viçosa (UFV), the bee collection at the Faculdade de Filosofia, Ciências e Letras de Ribeirão Preto (FFCLRP-USP), and the taxonomic collections center of the Universidade Federal de Minas Gerais (UFMG). All bee species were classified according to visiting behavior in tomato flowers as milking (insertion behavior of the proboscis in the cone formed by poricidal anthers to obtain pollen (Thorp, 2000), milking/robber (besides the insertion of the proboscis, the bees can damage the flower to obtain pollen) and sonicating ((behavior of vibrating the flower with the indirect muscles of the thorax (Russell et al., 2016)) based on observations at the time of collecting .

\subsection{Pollination Tests}

Pollination tests were conducted in August and September 2015 in the agriculture sector of the Instituto Federal do Norte de Minas (IFNMG-Campus Januária). A crop with 350 plants of the H9559® hybrid was utilized. The plants were distributed in six rows and spaced $1 \mathrm{~m}$ between rows and $0.5 \mathrm{~m}$ between plants. Four treatments with four replications were performed in randomized blocks, totaling 16 plots. The treatments were: single visit (SV), open pollination (OP), mechanical pollination (MP), and control (C); in this case, spontaneous self pollination took place. Pollination tests were performed with flowers of the first three bunches of 10 plants per plot. The number of flowers per bunch ranged from five to 11. These flowers were wrapped with organza bags before anthesis in all treatments except open pollination. In the SV treatment, the flowers were observed from 9 a.m. and 2 p.m. During this period the organza bags were removed from the flower bunches until they were pollinated by a single bee and were being bagged again. Bees of the genus Augochloropsis and Centris and the species Bombus brevivillus, Exomalopsis analis and Paratrigona lineata were recorded in SV treatment, but, due to loss of fruits by disease, only fruits pollinated by Augochloropsis, Centris and Paratrigona lineta were compared. The 
results were pooled in the SV treatment because the fruit weight and fruit set between the genus were similar (F $2,32=1.66, \mathrm{P}=0.2057$; F $2,32=0.66, \mathrm{P}=0.5240$ ). In the $\mathrm{OP}$, the flowers remained free for bee visits (we observed that the flowers in the OP received more than three visits by bees, usually more than one species). In MP, the flowers were vibrated daily for 5 seconds, between 9 a.m. and 2 p.m. from anthesis to senescence with a Bitufo ${ }^{\circledR}$ electric toothbrush adapted to vibrate flowers (Palma et al., 2008). In the $\mathrm{C}$ treatment, the flowers remained bagged until the beginning of fruit development. The schedules used to apply the treatments were based on the period of receptivity of the stigma that is greater between 10:30 a.m. and 3:30 p.m. (Del Sarto et al., 2005). The first three (of each plant) with ripe tomato fruit were harvested to evaluate the fruit set (\%), fresh fruit mass $(\mathrm{g})$ and seed numbers per fruit.

\subsection{Statistical Analyses}

The relationship between temperature and relative humidity and the number of bees collected on tomato flowers was estimated by polynomial regression analysis to evaluate how climatic variables affect bee activity. An ANOVA $(\alpha=0.05)$ was conducted to evaluate whether there was variation in fruit set $(\%)$, fresh fruit mass (g) and seed numbers per fruit as a function of pollination treatments. In cases where ANOVA was significant, the Tukey test $(\alpha=0.05)$ was used for multiple comparisons. The response variable values were submitted to the Shapiro-Wilk and Bartlett tests to verify the normality and homogeneity of variance, respectively. Spearman correlation analysis $(\alpha=0.05)$ was performed between the seeds and the fruit mass numbers. All calculations and analyses were conducted in R (R Core Team, 2017).

\section{Results}

\subsection{Bees'Fauna}

Seventy-seven and 63 sampling hours were spent in Norte of Minas Gerais and Zona da Mata, respectively. In both regions, 1,998 individuals were collected throughout the 3 years. Fifty-six species and morpho-species of 21 genera and three families were collected. Apidae represented $89.6 \%$ of the individuals collected, followed by Halictidae and Andrenidae, with 9.9 and $0.5 \%$ respectively. The Andrenidae family was collected only in the Zona da Mata region (Table 1).

The species abundance and richness was higher in the Zona da Mata region, with 1,180 individuals from 36 species. In the Norte de Minas, 818 individuals from 29 species were collected. Among the species collected, only nine $(16.07 \%)$ occurred in both regions. The species collected in both regions represented $60.56 \%$ of the bee community.

Exomalopsis analis was the most abundant species with $35.28 \%$ of the individuals collected followed by the honeybee (Apis mellifera), with $20.87 \%$. The five most abundant species represented $75.32 \%$ of the individuals. Exomalopsis analis was the only species collected in all fields and 21 species $(37.5 \%)$ occurred only in one of 11 fields. Most of the bees collected can vibrate the tomato flower.

Table 1. Family, species and abundance of bees collected in tomato crop in Norte de Minas (NM) and Zona da Mata (ZM), Minas Gerais state, Brazil in 2015 (015), 2016 (016) and 2017 (017) and total (T) individuals collected

\begin{tabular}{|c|c|c|c|c|c|}
\hline \multirow{2}{*}{ Family/Species } & \multicolumn{2}{|c|}{ NM } & \multicolumn{2}{|c|}{$\mathrm{ZM}$} & \multirow{2}{*}{$\mathrm{T}$} \\
\hline & 015 & 017 & 016 & 017 & \\
\hline \multicolumn{6}{|l|}{ Andrenidae } \\
\hline Oxaea flavescens Klug, 1807 & - & - & 2 & 2 & 4 \\
\hline Parapsaenythia serripes (Ducke, 1908) & - & - & 1 & 2 & 3 \\
\hline Psaenythia sp. & - & - & - & 3 & 3 \\
\hline \multicolumn{6}{|l|}{ Apidae } \\
\hline Apis mellifera Linnaeus, 1758 & 115 & 3 & 245 & 54 & 417 \\
\hline Bombus (Fervidobombus) brevivillus Franklin, 1913 & 28 & 74 & - & & 102 \\
\hline Bombus (Fervidobombus) morio (Swederus, 1787) & - & - & 10 & 19 & 29 \\
\hline Bombus (Fervidobombus) pauloensis Friese, 1913 & - & - & 4 & - & 4 \\
\hline Centris (Centris) aenea Lepeletier, 1841 & - & - & 1 & 1 & 2 \\
\hline Centris (Hemisiella) tarsata Smith, 1874 & 17 & 11 & - & 1 & 29 \\
\hline Centris (Hemisiella) trigonoides Lepeletier, 1841 & 41 & 23 & - & - & 64 \\
\hline
\end{tabular}




\begin{tabular}{|c|c|c|c|c|c|}
\hline Centris (Trachina) fuscata Lepeletier, 1841 & 2 & 4 & - & - & 6 \\
\hline Euglossa sp. & - & 1 & 1 & 1 & 3 \\
\hline Eulaema (Apeulaema) nigrita Lepeletier, 1841 & - & - & 1 & & 1 \\
\hline Exomalopsis (Exomalopsis) analis Spinola, 1853 & 74 & 35 & 301 & 295 & 705 \\
\hline Exomalopsis (Exomalopsis) auropilosa Spinola, 1853 & - & - & 32 & 75 & 107 \\
\hline Exomalopsis (Exomalopsis) fernandoi Moure, 1990 & - & - & - & 2 & 2 \\
\hline Exomalopsis (Exomalopsis) fulvofasciata Smith, 1879 & - & - & 2 & - & 2 \\
\hline Exomalopsis (Exomalopsis) minor Schrottky, 1910 & - & - & 1 & 8 & 9 \\
\hline Exomalopsis (Exomalopsis) tomentosa Friese, 1899 & - & - & - & 1 & 1 \\
\hline Exomalopsis (Exomalopsis) ypirangensis Schrottky, 1910 & - & - & 1 & 4 & 5 \\
\hline Melipona (Eomelipona) asilvai Moure, 1971 & 15 & - & - & - & 15 \\
\hline Melipona (Eomelipona) bicolor Lepeletier, 1836 & - & - & - & 1 & 1 \\
\hline Melipona (Melikerria) quinquefasciata Lepeletier, 1836 & - & 1 & - & - & 1 \\
\hline Melipona (Melipona) quadrifasciata Lepeletier, 1836 & 1 & - & 1 & - & 2 \\
\hline Nannotrigona testaceicornis (Lepeletier, 1836) & 2 & - & - & - & 2 \\
\hline Paratetrapedia sp. & - & - & 1 & 1 & 2 \\
\hline Paratrigona lineata (Lepeletier, 1836) & 144 & 30 & - & - & 174 \\
\hline Tetragonisca angustula (Latreille, 1811) & - & - & 5 & - & 5 \\
\hline Thygater (Thygater) analis (Lepeletier, 1841) & - & - & 4 & 16 & 20 \\
\hline Trigona hyalinata (Lepeletier, 1836) & 1 & - & - & - & 1 \\
\hline Trigona recursa Smith, 1863 & 4 & 36 & - & - & 40 \\
\hline Trigona sp. & 4 & - & - & - & 4 \\
\hline Trigona spinipes (Fabricius, 1793) & 12 & 3 & 12 & 3 & 30 \\
\hline Xylocopa (Neoxylocopa) cearensis Ducke, 1910 & 2 & - & - & - & 2 \\
\hline Xylocopa (Neoxylocopa) suspecta Moure \& Camargo, 1988 & - & - & - & 1 & 1 \\
\hline Xylocopa (Schonnherria) muscaria (Fabricius, 1775) & 1 & - & - & 1 & 2 \\
\hline
\end{tabular}

\section{Halictidae}

Augochlora (Oxystoglossella) sp.

Augochlora (Oxystoglossella) sp.2

Augochloropsis aff. iris

Augochloropsis argentina (Friese, 1908)

Augochloropsis brachycephala Moure, 1943

Augochloropsis cleopatra (Schrottky, 1902)

Augochloropsis cupreola (Cockerell, 1900)

Augochloropsis illustris (Vachal, 1903)

Augochloropsis melanochaeta Moure, 1950

Augochloropsis smithiana (Cockerell, 1900)

Augochloropsis sp.1

Augochloropsis sp. 2

Augochloropsis sp.4

Augochloropsis sp.5

Augochloropsis wallacei (Cockerell, 1900)

Dialictus sp.

Pseudaugochlora flammula Almeida, 2008

Pseudaugochlora graminea (Fabricius, 1804)

Pseudaugochlora indistincta Almeida, 2008

Pseudaugochlora pandora (Smith, 1853)

Abundance

Richness

$\begin{array}{ll}1 & - \\ - & 1 \\ 5 & 2 \\ 1 & - \\ - & - \\ 2 & - \\ - & - \\ 43 & 25 \\ - & 1 \\ - & - \\ - & - \\ - & - \\ - & - \\ - & - \\ - & - \\ - & 1 \\ 5 & - \\ 1 & 1 \\ - & - \\ 21 & 24 \\ 542 & 276 \\ 24 & 18\end{array}$

\begin{tabular}{lll}
- & - & 1 \\
- & - & 1 \\
- & - & 7 \\
2 & 8 & 11 \\
3 & 12 & 15 \\
- & - & 2 \\
- & 5 & 5 \\
- & - & 68 \\
- & - & 1 \\
1 & 5 & 6 \\
5 & 4 & 9 \\
- & 4 & 4 \\
1 & - & 1 \\
1 & - & 1 \\
- & 2 & 2 \\
- & - & 1 \\
- & - & 5 \\
5 & 4 & 11 \\
2 & - & 2 \\
- & - & 45 \\
645 & 535 & 1998 \\
26 & 28 & 56 \\
\hline & &
\end{tabular}




\subsection{Climate Variables and Flying Activity}

The relationship between climatic variables, temperature and relative humidity, and number of bees per flower was significant $\left(\mathrm{F}_{2,18}=27.16 ; \mathrm{P}<0.000\right.$ and $\left.\mathrm{F}_{2,33}=14.10 ; \mathrm{P}<0.000\right)$. Bees visited the tomato flowers at temperatures between $23^{\circ} \mathrm{C}$ to $39^{\circ} \mathrm{C}$ and relative humidity of $21 \%$ to $58 \%$, especially in the morning. In both regions, the bee activity peaked between 9 a.m. and 11 a.m. for all bee groups, except Bombus, with a peak at 8 a.m. (Figure 1). Bee visits to tomato flowers tend to decline after noon, with rare visits after 2 p.m.

\subsection{Bee Pollination}

The tomato fruit set $\left(\mathrm{F}_{3,11}=5.83 ; \mathrm{P}=0.0123\right)$ was higher in the SV and MP treatments, followed by OP and the control (Figure 2). The fresh fruit mass was higher for OP than in the SV and MP and lower in the control. The fruits of the OP were $33.5 \%$ heavier than the control ones. The seed numbers per fruit were similar in SV, OP and MP, and lower in the control. Correlation between the seed numbers per fruit and fresh fruit mass was not significant $(\mathrm{r}=0.29 ; \mathrm{P}=0.074)$.

\section{Discussion}

\subsection{Bees'Fauna}

The tomato bee fauna is composed mainly by sonicating bees, with a wide variety of social classes and nesting habits, which is important for the pollination service stability in agricultural enviroments. The Apidae abundance may be related to the great diversity of this group with diversified life histories. Species of this family have a range of social and forage behavior, besides nesting habits (Danforth et al., 2013). These characteristics allow Apidae to explore diverse environments, including those with intensive agriculture (Ferreira et al., 2015). Conditions such as bare ground for nesting (Potts et al., 2005) and food sources in cultivated areas (Blitzer et al., 2012; Montero-Castaño et al., 2016) can support higher species numbers. This pattern was common in studies on bee fauna in tomato crop with Apidae being dominant (Silva-Neto et al., 2013; Deprá et al., 2014; Santos et al., 2014).

The bee's greater abundance and richness in the Zona da Mata may be related to its more diverse landscape structure and composition compared to that of Norte de Minas Gerais, Brazil. Both regions are quite degraded, but the first has greater native forest patch numbers. These patches can provide food and nesting sources for bees, contributing to community diversification (Le Feon et al., 2010). On the other hand, nine species were common in both regions and represented $60.56 \%$ of the total abundance, indicating that the dominant fauna was practically similar in the two regions despite the differences in natural cover between thems.

The higher abundance of $E$. analis and its presence in all sites sampled show that this species can be favored in agricultural environments, possibly due to the avaibility of bare ground which can benefit species of underground nesting (Ferreira et al., 2015). On the other hand, intense soil disturbance in crop areas may affect underground species, but the possibility of nesting in the cultivated area, especially in carriers where the soil is compacted, may favor E. analis (Potts et al., 2005; Julier \& T'ai, 2009). The high abundance Exomalopsis analis and its occurrence in all sites, allied with its sonication behavior, indicate that this species is an important pollinator of the tomato. This species was also the most abundant in other studies on community of bees in tomato fields of Goiás, Rio de Janeiro and Triângulo Mineiro (Silva-Neto et al., 2013; Deprá et al., 2014; Santos et al., 2014), reinforcing its importance for the tomato crop. 

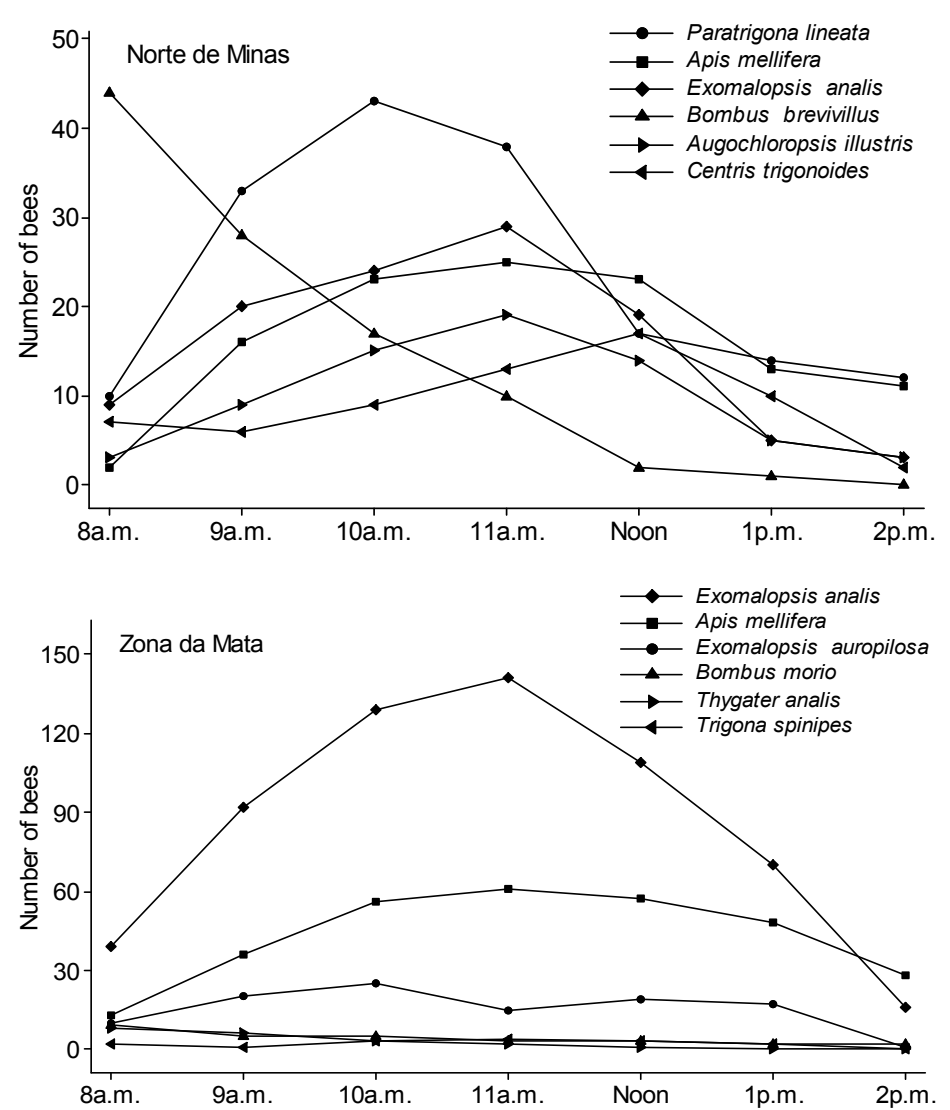

Figure 1. Activity of the main bee species on tomato flower during the day in Norte de Minas and Zona da Mata regions, Minas Gerais, Brazil

The high numbers of honeybee individuals may be related to characteristics of this species such as nests with thousands of individuals and the ability to trace and recruit nestmates to many food sources through a sophisticated communication and labor system division. In agricultural environments, the mass flowering of other crops during the off-season of the tomato crop may favor this species maintenance in the area (Blitzer et al., 2012; Blaauw \& Isaacs, 2014; Montero-Castaño et al., 2016). We were not aware of any apiaries near the study fields, so individuals may have been from feral nests. On the other hand, the honeybee is a less efficient pollinator than other bees because it does not sonicate flowers and obtains tomato pollen by inserting the proboscis into the anther cone (Dos Santos et al., 2009), behavior known as milking. However, the large visit numbers that this species performs per flower can compensate the relative inefficiency of a single honeybee visit (Macias-Macias et al., 2009).

The predominance of sonicating bees in tomato crops can be explained by the efficiency of this group in extracting pollen from poricidal anthers, which plays an important role in tomato pollination (Greenleaf \& Kremen, 2006). On the other hand, non-sonicating bees may not be attracted to tomato due to the absence of nectar in the flower of this plant and the difficulty of extracting pollen from its poricidal anther (King \& Buchmann, 2003). However, in our study, the presence of non-sonicating bees in tomato crops may be related to the absence or low availability of other pollen sources besides the tomato in the areas sampled. 


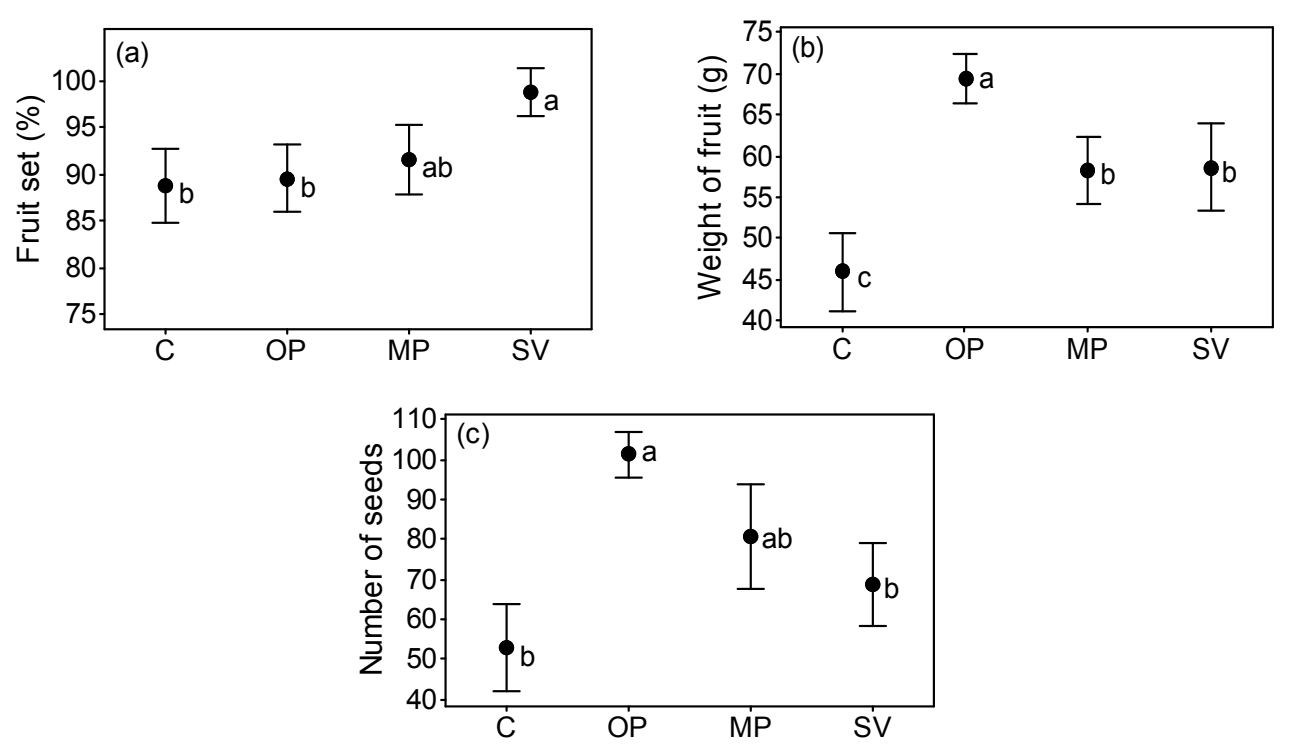

Figure 2. Fruit set (a), fruit weight in grams (b) and number of seeds per fruit (c) in function of control (C), open pollination (OP), mechanical pollination (MP) and single visit (SV). Means and standard error bars are shown for four experimental treatments. Bars followed by the same lowercase letter do not differ by the Tukey test $(\alpha=0.05)$

\subsection{Climate Variables and Flying Activity}

The lower temperature may have favored greater Bombus activity early in the morning, since larger black bees may present difficulties with dehydration and thermal regulation at high temperatures (Pereboom \& Biesmeijer, 2003). Different foraging peaks per species indicate the possibility of temporal tomato pollen partition (Roubik, 1989). These differences may increase pollination efficiency due to complementarity between different bee species (Martins et al., 2015). In addition, the period of higher activity of the pollinators corresponds, in part, to the period of greater receptivity of the stigma in the tomato, which is from 10:30 a.m. to 3:30 p.m. (Del Sarto et al., 2005).

On the other hand, knowledge about the variation in flight activity of bees throughout the day could be used in the planning of spraying of pesticides. This should be done in periods that do not coincide with those of greater activity for these insects to minimize their contact with the pesticides. These products should be applied after 2 p.m. to allow a longer interval between bee visits and spraying.

\subsection{Bee Pollination}

The highest fruit set in the SV treatment indicates that a single bee visit was sufficient for the fruit set, which may be related to the pollen amount extracted from the flower in the first visit. Bombus (Pyrobombus) impatiens Cresson 1863 (Bombini: Apidae) removes 57.8\% of the pollen from tomato anthers at its first visit and this quantity is sufficient to fertilize the flower (Nunes-Silva et al., 2013). On the other hand, the mechanical stimuli absence in flowers in the control may have led to lower pollen deposition on the stigma and, consequently, flower abortion, resulting in lower fruit production.

Multiple visits by different bee species in the OP may have allowed greater pollen deposition on the stigma and, hence, the heavier fruit formation (Silva-Neto et al., 2013). The possibility of different pollinator species visiting the same flower should be considered in OP, and this may improve pollination services due to the behavioral particularities of each functional group that complement each other in time and space (Hoehn et al., 2008; Gagic et al., 2015; Martins et al., 2015). The lighter fresh fruit mass with MP demonstrates the lower efficiency of this method. Mechanical pollination was performed several times, but the vibration frequency of the equipment may not have been compatible with that required for efficient pollen release (Palma et al., 2008).

The similar seed numbers in tomato fruits in SV, OP, and MP treatments reinforce the correlation lack between fruit mass and seed numbers. The fruit tomato development generally depends on pollination and fertilization, demonstrating the importance of seed formation for their growth (Shinozaki et al., 2015). However, it is possible that other factors have affected the relationship between fruit mass and number of seeds, including the possibility 
of genes being involved in forming parthenocarpic fruits (Mazzucato et al., 2015). In any case, the fruit mass seems to be more important for the grower than the number of seeds per fruit.

\section{Conclusion}

Our results support the general hypothesis that few species dominate bees' fauna in agricultural environments. However, contrary to our expectations, a single visit by a bee to the flower did not result in heavier fruits compared to open pollination when, supposedly, the flower was visited more than once by different species. Thus, we emphasize the importance of more diverse communities for the efficiency and stability of pollination services. Considering that the loss of diversity is associated with several factors, including intensification of agriculture, future studies on how the community of bees responds to landscape changes and farm management are needed.

\section{Acknowledgements}

We would like to thank professors Eduardo Andrade Botelho de Almeida (FFCLRP-USP) and Fernando Amaral da Silveira (UFMG) for the identification of part of the bees collected; the Conselho Nacional de Desenvolvimento Científico e Tecnológico (CNPQ) and the Fundação de Amparo à Pesquisa do Estado de Minas Gerais (FAPEMIG) for their financial support; the Karambi Alimentos company for support during field work; and the Eagle Seeds company for supplying the tomato H9553 ${ }^{\circledR}$ and H9992 $®$ hybrids. F. M. B. received support from PBQS/IFNMG-Campus Januária (223/2014; 066/2015; 086/2016; 173/2017).

\section{References}

Bartelli, B. F., \& Nogueira-Ferreira, F. H. (2014). Pollination services provided by Melipona quadrifasciata Lepeletier (Hymenoptera: Meliponini) in greenhouses with Solanum lycopersicum L. (Solanaceae). Sociobiology, 61(4), 510-516. https://doi.org/10.13102/sociobiology.v61i4.510-516

Blaauw, B. R., \& Isaacs, R. (2014). Flower plantings increase wild bee abundance and the pollination services provided to a pollination-dependent crop. Journal of Applied Ecology, 51(4), 890-898. https://doi.org/ $10.1111 / 1365-2664.12257$

Blitzer, E. J., Dormann, C. F., Holzschuh, A., Klein, A. M., Rand, T. A., \& Tscharntke, T. (2012). Spillover of functionally important organisms between managed and natural habitats. Agriculture, Ecosystems \& Environment, 146(1), 34-43. https://doi.org/10.1016/j.agee.2011.09.005

Brittain, C., Kremen, C., Garber, A., \& Klein, A. M. (2014). Pollination and plant resources change the nutritional quality of almonds for human health. PloS One, 9(2), e90082. https://doi.org/10.1371/journal. pone.0090082

Burkle, L. A., Marlin, J. C., \& Knight, T. M. (2013). Plant-pollinator interactions over 120 years: Loss of species, co-occurrence, and function. Science, 339(6127), 1611-1615. https://doi.org/10.1126/science.1232728

Connelly, H., Poveda, K., \& Loeb, G. (2015). Landscape simplification decreases wild bee pollination services to strawberry. Agriculture, Ecosystems \& Environment, 211, 51-56. https://doi.org/10.1016/j.agee.2015. 05.004

Cusser, S., Neff, J. L., \& Jha, S. (2016). Natural land cover drives pollinator abundance and richness, leading to reductions in pollen limitation in cotton agroecosystems. Agriculture, Ecosystems \& Environment, 226, 33-42. https://doi.org/10.1016/j.agee.2016.04.020

Danforth, B. N., Cardinal, S., Praz, C., Almeida, E. A., \& Michez, D. (2013). The impact of molecular data on our understanding of bee phylogeny and evolution. Annual Review of Entomology, 58, 57-78. https://doi.org/10.1146/annurev-ento-120811-153633

De Luca, P. A., \& Vallejo-Marín, M. (2013). What's the 'buzz'about? The ecology and evolutionary significance of buzz-pollination. Current Opinion in Plant Biology, 16(4), 429-435. https://doi.org/10.1016/j.pbi.2013. 05.002

Deguines, N., Jono, C., Baude, M., Henry, M., Julliard, R., \& Fontaine, C. (2014). Large-scale trade-off between agricultural intensification and crop pollination services. Frontiers in Ecology and the Environment, 12(4), 212-217. https://doi.org/10.1890/130054

Del Sarto, M. C. L., Peruquetti, R. C., \& Campos, L. A. O. (2005). Evaluation of the neotropical stingless bee Melipona quadrifasciata (Hymenoptera: Apidae) as pollinator of greenhouse tomatoes. Journal of Economic Entomology, 98(2), 260-266. https://doi.org/10.1603/0022-0493-98.2.260 
Deprá, M. S., Delaqua, G., Carla, G., Freitas, L., \& Gaglianone, M. C. (2014). Pollination deficit in open-field tomato crops (Solanum lycopersicum L., Solanaceae) in Rio de Janeiro state, southeast Brazil. Journal of Pollination Ecology, 12, 1-8.

Dos Santos, S. A., Roselino, A. C., Hrncir, M., \& Bego, L. R. (2009). Pollination of tomatoes by the stingless bee Melipona quadrifasciata and the honey bee Apis mellifera (Hymenoptera, Apidae). Genetics and Molecular Research, 8(2), 751-757. https://doi.org/10.4238/vol8-2kerr015

Eeraerts, M., Meeus, I., Van Den Berge, S., \& Smagghe, G. (2017). Landscapes with high intensive fruit cultivation reduce wild pollinator services to sweet cherry. Agriculture, Ecosystems \& Environment, 239, 342-348. https://doi.org/10.1016/j.agee.2017.01.031

FAOSTAT. (2018). Food and Agriculture Organization of the United Nations. Retrieved from https://faostat.fao.org

Ferreira, P. A., Boscolo, D., Carvalheiro, L. G., Biesmeijer, J. C., Rocha, P. L., \& Viana, B. F. (2015). Responses of bees to habitat loss in fragmented landscapes of Brazilian Atlantic Rainforest. Landscape Ecology, 30(10), 2067-2078. https://doi.org/10.1007/s10980-015-0231-3

Gagic, V., Bartomeus, I., Jonsson, T., Taylor, A., Winqvist, C., Fischer, C., ... Tscharntke, T. (2015). Functional identity and diversity of animals predict ecosystem functioning better than species-based indices. Proceedings of the Royal Society B: Biological Sciences, 282(1801), 20142620. https://doi.org/10.1098/ rspb.2014.2620

Gallai, N., Salles, J. M., Settele, J., \& Vaissière, B. E. (2009). Economic valuation of the vulnerability of world agriculture confronted with pollinator decline. Ecological Economics, 68(3), 810-821. https://doi.org/ 10.1016/j.ecolecon.2008.06.014

Garibaldi, L. A., Steffan-Dewenter, I., Winfree, R., Aizen, M. A., Bommarco, R., Cunningham, S. A., ... Bartomeus, I. (2013). Wild pollinators enhance fruit set of crops regardless of honey bee abundance. Science, 339(6127), 1608-1611. https://doi.org/10.1126/science.1230200

Goulson, D., Lye, G. C., \& Darvill, B. (2008). Decline and conservation of bumble bees. Annual Review of Entomology, 53, 191-208. https://doi.org/10.1146/annurev.ento.53.103106.093454

Greenleaf, S. S., \& Kremen, C. (2006). Wild bee species increase tomato production and respond differently to surrounding land use in Northern California. Biological Conservation, 133(1), 81-87. https://doi.org/ 10.1016/j.biocon.2006.05.025

Hanna, H. Y. (1999). Assisting natural wind pollination of field tomatoes with an air blower enhances yield. HortScience, 34(5), 846-847. https://doi.org/10.21273/HORTSCI.34.5.846

Hoehn, P., Tscharntke, T., Tylianakis, J. M., \& Steffan-Dewenter, I. (2008). Functional group diversity of bee pollinators increases crop yield. Proceedings of the Royal Society B: Biological Sciences, 275(1648), 2283-2291. https://doi.org/10.1098/rspb.2008.0405

Holzschuh, A., Dudenhöffer, J. H., \& Tscharntke, T. (2012). Landscapes with wild bee habitats enhance pollination, fruit set and yield of sweet cherry. Biological Conservation, 153, 101-107. https://doi.org/ 10.1016/j.biocon.2012.04.032

Julier, H. E., \& T'ai, H. R. (2009). Wild bee abundance and pollination service in cultivated pumpkins: Farm management, nesting behavior and landscape effects. Journal of Economic Entomology, 102(2), 563-574. https://doi.org/10.1603/029.102.0214

Kennedy, C. M., Lonsdorf, E., Neel, M. C., Williams, N. M., Ricketts, T. H., Winfree, R., ... Carvalheiro, L. G. (2013). A global quantitative synthesis of local and landscape effects on wild bee pollinators in agroecosystems. Ecology Letters, 16(5), 584-599. https://doi.org/10.1111/ele.12082

King, M. J., \& Buchmann, S. L. (2003). Floral sonication by bees: mesosomal vibration by Bombus and Xylocopa, but not Apis (Hymenoptera: Apidae), ejects pollen from poricidal anthers. Journal of the Kansas Entomological Society, 76, 295-305.

Klatt, B. K., Holzschuh, A., Westphal, C., Clough, Y., Smit, I., Pawelzik, E., \& Tscharntke, T. (2014). Bee pollination improves crop quality, shelf life and commercial value. Proceedings of the Royal Society B: Biological Sciences, 281(1775), 20132440. https://doi.org/10.1098/rspb.2013.2440 
Kleijn, D., Winfree, R., Bartomeus, I., Carvalheiro, L. G., Henry, M., Isaacs, R., ... Ricketts, T. H. (2015). Delivery of crop pollination services is an insufficient argument for wild pollinator conservation. Nature Communications, 6, 7414. https://doi.org/10.1038/ncomms 8414

Klein, A. M., Vaissiere, B. E., Cane, J. H., Steffan-Dewenter, I., Cunningham, S. A., Kremen, C., \& Tscharntke, T. (2006). Importance of pollinators in changing landscapes for world crops. Proceedings of the Royal Society B: Biological Sciences, 274(1608), 303-313. https://doi.org/10.1098/rspb.2006.3721

Le Féon, V., Schermann-Legionnet, A., Delettre, Y., Aviron, S., Billeter, R., Bugter, R., ... Burel, F. (2010). Intensification of agriculture, landscape composition and wild bee communities: a large scale study in four European countries. Agriculture, Ecosystems \& Environment, 137(1-2), 143-150. https://doi.org/10.1016/ j.agee.2010.01.015

Macias-Macias, O., Chuc, J., Ancona-Xiu, P., Cauich, O., \& Quezada-Euán, J. J. G. (2009). Contribution of native bees and Africanized honey bees (Hymenoptera: Apoidea) to Solanaceae crop pollination in tropical México. Journal of Applied Entomology, 133(6), 456-465. https://doi.org/10.1111/j.1439-0418.2009. 01399.x

Martins, K. T., Gonzalez, A., \& Lechowicz, M. J. (2015). Pollination services are mediated by bee functional diversity and landscape context. Agriculture, Ecosystems \& Environment, 200, 12-20. https://doi.org/ 10.1016/j.agee.2014.10.018

Mazzucato, A., Cellini, F., Bouzayen, M., Zouine, M., Mila, I., Minoia, S., ... Carriero, F. (2015). A TILLING allele of the tomato Aux/IAA9 gene offers new insights into fruit set mechanisms and perspectives for breeding seedless tomatoes. Molecular Breeding, 35(1), 22. https://doi.org/10.1007/s11032-015-0222-8

Mogren, C. L., Rand, T. A., Fausti, S. W., \& Lundgren, J. G. (2016). The effects of crop intensification on the diversity of native pollinator communities. Environmental Entomology, 45(4), 865-872. https://doi.org/ 10.1093/ee/nvw066

Montero-Castaño, A., Ortiz-Sánchez, F. J., \& Vilà, M. (2016). Mass flowering crops in a patchy agricultural landscape can reduce bee abundance in adjacent shrublands. Agriculture, Ecosystems \& Environment, 223, 22-30. https://doi.org/10.1016/j.agee.2016.02.019

Nunes-Silva, P., Hnrcir, M., Shipp, L., Imperatriz-Fonseca, V. L., \& Kevan, P. G. (2013). The behaviour of Bombus impatiens (Apidae, Bombini) on tomato (Lycopersicon esculentum Mill., Solanaceae) flowers: pollination and reward perception. Journal of Pollination Ecology, 11(5), 33-40.

Palma, G., Quezada-Euán, J. J. G., Reyes-Oregel, V., Meléndez, V., \& Moo-Valle, H. (2008). Production of greenhouse tomatoes (Lycopersicon esculentum) using Nannotrigona perilampoides, Bombus impatiens and mechanical vibration (Hym.: Apoidea). Journal of Applied Entomology, 132(1), 79-85. https://doi.org/ 10.1111/j.1439-0418.2007.01246.x

Pereboom, J. J. M., \& Biesmeijer, J. C. (2003). Thermal constraints for stingless bee foragers: The importance of body size and coloration. Oecologia, 137(1), 42-50. https://doi.org/10.1007/s00442-003-1324-2

Potts, S. G., Vulliamy, B., Roberts, S., O'Toole, C., Dafni, A., Ne'eman, G., \& Willmer, P. (2005). Role of nesting resources in organising diverse bee communities in a Mediterranean landscape. Ecological Entomology, 30(1), 78-85. https://doi.org/10.1111/j.0307-6946.2005.00662.x

Potts, S. G., Roberts, S. P., Dean, R., Marris, G., Brown, M. A., Jones, R., ... Settele, J. (2010). Declines of managed honey bees and beekeepers in Europe. Journal of Apicultural Research, 49(1), $15-22$. https://doi.org/10.3896/IBRA.1.49.1.02

R-Core-Team. (2017). R: A language and environment for statistical computing. R Foundation for Statistical Computing, Vienna, Austria. Retrieved from https://www.R-project.org

Rader, R., Bartomeus, I., Garibaldi, L. A., Garratt, M. P., Howlett, B. G., Winfree, R., ... Bommarco, R. (2016). Non-bee insects are important contributors to global crop pollination. Proceedings of the National Academy of Sciences, 113(1), 146-151. https://doi.org/10.1073/pnas.1517092112

Roubik, D. W. (1989). Ecology and natural history of tropical bees. New York, NY: Cambridge University Press. https://doi.org/10.1017/CBO9780511574641

Santos, A. O. R., Bartelli, B. F., \& Nogueira-Ferreira, F. H. (2014). Potential pollinators of tomato, Lycopersicon esculentum (Solanaceae), in open crops and the effect of a solitary bee in fruit set and quality. Journal of Economic Entomology, 107(3), 987-994. https://doi.org/10.1603/EC13378 
Shinozaki, Y., Hao, S., Kojima, M., Sakakibara, H., Ozeki - Iida, Y., Zheng, Y., ... Okabe, Y. (2015). Ethylene suppresses tomato (Solanum lycopersicum) fruit set through modification of gibberellin metabolism. The Plant Journal, 83(2), 237-251. https://doi.org/10.1111/tpj.12882

Silva-Neto, C. M., Lima, F. G., Gonçalves, B. B., Bergamini, L. L., Bergamini, B. A. R., Elias, M. A., \& Franceschinelli, E. V. (2013). Native bees pollinate tomato flowers and increase fruit production. Journal of Pollination Ecology, 11(6), 41-45.

Strange, J. P. (2015). Bombus huntii, Bombus impatiens, and Bombus vosnesenskii (Hymenoptera: Apidae) pollinate greenhouse-grown tomatoes in western North America. Journal of Economic Entomology, 108(3), 873-879. https://doi.org/10.1093/jee/tov078

Thorp, R. W. (2000). The collection of pollen by bees. Plant Systematics and Evolution, 222, 211-223. https://doi.org/10.1007/BF00984103

Winfree, R., W. Fox, J., Williams, N. M., Reilly, J. R., \& Cariveau, D. P. (2015). Abundance of common species, not species richness, drives delivery of a real-world ecosystem service. Ecology Letters, 18(7), 626-635. https://doi.org/10.1111/ele.12424

Zou, Y., Bianchi, F. J., Jauker, F., Xiao, H., Chen, J., Cresswell, J., ... van der Werf, W. (2017). Landscape effects on pollinator communities and pollination services in small-holder agroecosystems. Agriculture, Ecosystems \& Environment, 246, 109-116. https://doi.org/10.1016/j.agee.2017.05.035

\section{Appendix A}

Table A1. Characteristics of the sites and tomato crops used for the sampling of bees in Norte de Minas and Zona da Mata, Minas Gerais, Brazil

\begin{tabular}{lllll}
\hline & \multicolumn{3}{c}{ Municipality } \\
\cline { 2 - 5 } & Cajuri & Coimbra & Januária & Manga \\
\hline Region & Zona da Mata & Zona da Mata & Norte de Minas & Norte de Minas \\
Natural cover & Atlantic Forest* & Atlantic Forest & Savanna/SDTF** & Savanna/SDTF \\
Climate type (Köepen) & Cwa & Cwa & Aw & Aw \\
Sampling year & 2016 & $2016 / 2017$ & $2015 / 2017$ & 2015 \\
Number of fields sampled & 1 & 5 & 4 & 1 \\
Size of tomato crop (ha) & 0.3 & $0.2-0.4$ & $0.3-2.0$ & 30 \\
Variety & Aguamiel ${ }^{\circledR}$ & Aguamiel ${ }^{\circledR}$ & H9553®/H9992® & H9553® \\
Tomato growing & Indeterminate & Indeterminate & Determinate & Determinate \\
Spacing (m) & $0.5 \times 1.2$ & $0.5 \times 1.2$ & $0.5 \times 1.0$ & $0.3 \times 1.2$ \\
Irrigation system & Drip & Drip & Aspersion/Drip & Central pivot \\
Farming practices & Conventional & Conventional & Conventional & Conventional \\
\hline
\end{tabular}

Note. ${ }^{*}$ Atlantic Forest $=$ Brazilian Atlantic forest; $* *$ Savanna $=$ Brazilian Cerrado/SDTF $($ Seasonally dry tropical forest $)=$ Brazilian Caatinga [Based in Pennington and Lavin (2015) modified from Olson et al. (2001)].

\section{Copyrights}

Copyright for this article is retained by the author(s), with first publication rights granted to the journal.

This is an open-access article distributed under the terms and conditions of the Creative Commons Attribution license (http://creativecommons.org/licenses/by/4.0/). 